specialization. A fundamental problem confronting the chemist is that of acquiring a proper education leading to a cultured outlook and fitting him to take his place in the world of men and affairs. What steps can be taken to combat the narrowing outlook which threatens to affect science students at all levels, and to provide for their social, cultural and spiritual needs?

Formerly a chemistry student was trained to become an all-round practitioner of his art; but latterly the vision of the student and research worker has narrowed. We have entered into an age of teamwork. Chemical science has been aided nobly by such work; but the individual worker is liable to sacrifice a great deal in the process.

The mental effect of an unrelieved absorption in a specialized field of science has been vividly described by Charles Darwin, and the growth of such specialization in later times has led to many criticisms of its effect upon the human subject.

It is in the schools that we view the education of the incipient scientific worker in its broadest aspect; and it is here, helped in the ideal case by home influences, that the foundations of the necessary wider interests must be firmly laid. There ought to be no sense of antagonism between arts and science, and any form of modern education should be made up of a proper blend of each. A lively interest in literature, history, art, music or the drama, gained in early life and nurtured thereafter, would do much to solve some of the problems of specialization in science. Highly specialized teaching in science ought to be avoided in the schools.

In the universities, the way of teaching chemistry is of the first importance. Although his chemical studies must deepen rather than broaden as the student passes onwards towards research, he should always be encouraged to realize that there are a chemical geography and a chemical history, and that these offer him avenues leading to a wider horizon. Chemistry itself may become a cultural and humanistic instrument of high value. Historical chemistry is linked in turn with philosophy, literature, art, and even with music. During the student's undergraduate days a great deal could be done to arm him against the dangers of specialization, and more importance should be attached to the technique of teaching from this point of view.

During postgraduate research work the student should be encouraged to undertake a certain amount of teaching work in the junior laboratories. $\mathrm{He}_{\boldsymbol{\theta}}$ should also use opportunities to migrate to new research centres either at home or abroad. A research theme of a suitable kind ought to help the student to becoms resourceful and to develop originality of thought, besides stimulating his imaginative and critical powers; unfortunately, research themes often fail to fulfil these requirements. Finally, the proper education and training of the young scientific worker, with the application of the various influences that have been mentioned, including personal contact with his teachers, call for the provision of adequate staff and accommodation.

\section{GEOLOGY TO-DAY AND TO-MORROW}

1 HE theme of Dr. A. E. Trueman's presidential address to Section 'C (Geology) is the future of geology. At the present time, he points out, geology is passing through a period of very active growth. It is doubtful if at any time since the 'heroic age' of the science, a hundred and fifty years ago, there has been so rapid an increase in our knowledge of earth history. More geologists are professionally employed in all parts of the world ; many more fields of human activity are dependent on the success of their operations than ever before. They search for ores, coal, oil and water. If in the future we are to depend on atomic energy for some of our power, it will need geologists to locate the new materials. Inevitably, we shall be driven to exploit mineral resources occurring at greater depths, or of poorer quality ; while we continue to use materials from the earth's crust the geologist will have an increasing part to play in their discovery. In the course of these explorations much new information is being gathered, but many major problems still await solution.

Although geology is in this phase of active development, its results and methods are probably less familiar to the educated public in Britain than those of any of the other fundamental sciences. This widespread unawareness of geology, which is not found in most other countries, is in marked contrast with the position of fifty to a hundred years ago and calls for serious attention, for it cannot be held that any science is in a healthy condition if its work is insufficiently understood by laymen. The absence of almost any geology teaching in schools and the scarcity of teachers with any acquaintance with the subject are partly responsible for present conditions. It is claimed that geology should form part of a wide cultural education; it can serve as a link between science and more humane studies or as a basis for a new type of synthesis.

Fortunately, the comparative lack of public interest in geology has not in recent years limited the recognition of its value by Government. Much has happened to stimulate the demand for geological advice for a variety of economic purposes, both in Britain and overseas. In the limited area of Great Britain, the Geological Survey, founded more than a hundred years ago, not only meets new demands for more detailed maps but also is required to undertake great new responsibilities. The record of its work in war years, recently published, exemplifies the wide range of activities in which geological information is necessary; in view of the growing importance of the work of the Survey, the need for an expansion of its numbers has been recognized. The Colonial surveys, even more in need of increased support, are accepted as having a vital part in the economic development of the Colonial territories. The present Secretary of State for the Colonies has himself on several occasions appealed to young men to take up the work of geologists in these areas. The small surveys of the past have been sparsely staffed, one geologist being responsible for thirty times the area for which a member of the home survey was responsible. In the past, several Colonial geological surveys have paid for their own cost many times over by discoveries of diamonds and ores, but future results must not be judged only in terms of exportable minerals ; more bulky materials, such as limestones, clays, road materials and especially water, may contribute even more to the development of the territories. Along. side these developments of geological survey activity throughout the Commonwealth, the promotion of researches by unofficial geologists is equally essential.

In the immediate future we must expect an increasing tendency to specialization in limited fields and particularly on the fringes of the subject, as on 
the borderlines between geology and physics, or geology and chemistry. Advances in such fields as geophysics call for workers with more extensive training in the two subjects. The ca operation of geophysicist and geologist makes possible the interpretation of concealed structures: England south from the Wash requires special study in view of the possibilities of new coalfields. But on a wider front we may expect to learn more of submarine areas, of the structure and origin of mountains and of the larger features of the earth. Work in geochemistry, in the distribution of minerals, the origin of rocks and the nature of clays, promizes rapid development. In the fields of geomorphology the problems are barely touched; in palæontology the existing data only serve to illustrate the extent of the problems to be solved. But in all these extensions of knowledge it may be hoped that it will be possible to avoid the isolation of the fields of study, relating them all to stratigraphy and the study of the structure of the earth's crust which form the 'heart of geology'.

\section{TEACHING ZOOLOGY IN THE UNIVERSITY}

$\mathrm{P}$

ROF. H. GRAHAM CANNON discusses "Under. graduate Zoology" in his presidential address to Section D (Zoology). After the First World War, he says, the interest in zoology became almost exclusively experimental. The more orthodox attitude of comparative anatomy became the one to be avoided. This was due to a variety of reasons, but largely because, for generations, zoologists had been teaching the comparative anatomy of dead animals without worrying about how these animals lived. As a result of this changed outlook between the two World Wars, a generation of teachers has grown up who are predominantly experimentalists, and our present undergraduates run the risk of becoming very knowledgeable about the latest developments of experimental technique while knowing very little indeed about the anatomy of the animals on which they work. Recently, but somewhat tardily, it has become recognized that there is such an aspect of zoology as functional morphology, that is, a method of treatment where suructures are dealt with not merely in the way in which they are built, but also, and at the same time, from the way in which they function. It is this attitude which should form the basis of undergraduate zoology.

Two main difficulties present themselves in considering the teaching of zoology to undergraduates. First, there is the modern tendency to scorn any elementary teaching and to thrust the first year's university work back on to the schools. This misguided attitude may be excusable in the more basic physical sciences and mathematics: but in the biological sciences, which, after all, utilize the physical sciences as their tools, it is completely illogical. Moreover, it is essential that the more experienced teachers, preferably the professor, should always deal with this fundamental first year's introduction to university study.

- Secondly, there is the tendency almost everywhere to introduce specialist courses into the undergraduate years : a tendency which is being encouraged by the efforts of the University Grants Committee to foster the establishment of readerships or even chairs in the most abstruse specialist aspects of biology. At the undergraduate stage the students are quite unable to assimilate such courses. The sort of courses which are being established are those admirably suited for the second part of the Cambridge Tripos. But what is almost invariably overlooked is that the second part is entirely a postgraduate course. The honours degree is given on the first part of the Tripos, and this corresponds to the degrees in the 'Redbrick Universities' of honours general science. It is suggested that it would be a great advantage in all 'Redbrick Univer. sities' to abolish the specialist honours degree altogether and insist on a first degree being taken in general science as at Cambridge. The more specialist attitude to the subject could then be left to a postgraduate year, leading preferably to a master's degree.

\section{SOCIAL GEOGRAPHY}

$I^{\mathrm{N}}$ $\mathrm{T}$ his presidential address to Section E (Geography), Lord Rennell of Rodd deals with the geographical environment of man as a social animal, and con. sequently does not attempt to consider the geographical circumstances of the origin of human species or prehistoric man. But the spiritual as well as the material consequences of geography on human society are considered rather by posing a series of questions, and stating a number of problems, especially in connexion with Africa, than by proposing conclusions or solutions.

Starting from the influence of geography on the spiritual as well as on the material development of society, Lord Rennell makes a strong plea, which he takes up again at the end of the address, for the teaching of geography in medium and higher education as a means of creating a bridge between the humanities and the natural sciences, which "except among the leaders of the latter group" have more and more tended to develop on independent lines divorced from each other. This tendency he dates from the decline in classical education; but he sees in geography, and especially in social geography, a new link which could be made between the two, in view of the manifold contacts which geography has with both the exact and the abstract realms of human thought.

From this point he goes on to discuss a number of problems arising in Africa. What are the reasons why Islam spread as far as the southern rim of the North African deserts but never affected the popu. lation south of the northern fringe of the forest belt ? Why was the negro and negroid population of Africa antagonistic to outside civilization in spite of many opportunities of contact with more civilized people from Greek and Carthaginian times through all the period of Arab and Portuguese navigation until the European conquest? Why then, and only then, did a ferment of Western civilization begin, within say the last seventy years? Yet the civilizing influence of the Mediterranean found no difficulty in crossing the Sahara and following up the Niles until they came to a dead end against the unwillingness of the negro to adopt or adapt. Why is there no trace of writing or even ideography in Dark Africa? Why was there no true architecture, the wheel or the plough in Africa south of the deserts until the conquering European started the modern phase?

Lord Rennell goes on to discuss the anomalous and absurd consequences of the European conquest, the purpose of which, in spite of Lord Hailey's investigations, remains very obscure. He refers to 